\title{
Komparácia vybraných rýchlostných schopností juniorov z hladiska hráčskych postov v l'adovom hokeji
}

\section{Comparation of the selected speed abilities of juniors ice hockey players between defenders and forwards}

\author{
Rastislav Palov \\ Filozofická fakulta, Univerzita Mateja Bela, Banská Bystrica, Slovensko
}

\begin{abstract}
Abstrakt
Cielom štúdie bolo porovnat' aktuálnu úroveň vybraných rýchlostných schopností juniorských hokejistov medzi obrancami a útočníkmi $(n=20$, výška $=182,3 \pm 4,9 \mathrm{~cm}$, hmotnost' $=81,5 \pm 6,7 \mathrm{~kg}$, vek $=18,44 \pm 0,70$ roka; obrancovia $=8$, výška $=184,0 \pm 3,8 \mathrm{~cm}$, hmotnost' $=84,2 \pm 6,5 \mathrm{~kg}$, vek $=18,60 \pm$ 0,59 roka; útočníci $=12$, výška $=181,2 \pm 5,4 \mathrm{~cm}$, hmotnost $^{\prime}=79,6 \pm 6,7 \mathrm{~kg}$, vek $=18,33 \pm 0,77$ roka) $v$ sútažnom ročníku 2014/2015. Indikátory vybraných rýchlostných schopností boli zistované dvomi testami: 1. Beh na $40 \mathrm{~m}$ so zmenami smeru a 2. Test agility - Illinois. Štatistická analýza bola realizovaná pomocou software IBM ${ }^{\circledast}$ SPSS ${ }^{\circledast}$ Statistics V19. Priemerná hodnota $v$ teste beh na $40 \mathrm{~m}$ so zmenami smeru celého súboru bola 8,52 $\pm 0,22 \mathrm{~s}$, u obrancov bola 8,34 $\pm 0,10$ s a u útočníkov $8,64 \pm 0,19 \mathrm{~s}$, čo je štatisticky významný rozdiel medzi obrancami a útočníkmi $(d=1,97 ; p<0,05 ; r=0,70$ - vel'ký efekt) $v$ prospech obrancov. $V$ teste agility - Illinois bola priemerná hodnota celého súboru 16,58 $\pm 0,33 \mathrm{~s}$. U obrancov bol priemerný výsledný čas indikovaný hodnotou 16,32 $\pm 0,23$ s a u útočníkov $16,75 \pm 0,27$ $s$, čo je opät štatisticky významný rozdiel v prospech obrancov $(d=1,71 ; p<0,05 ; r=0,65$ - velký efekt).
\end{abstract}

\begin{abstract}
The aim of the study was to compare the current level of the selected speed abilities of juniors hockey players between defenders and forwards $(n=20$, height $=182.3 \pm 4.9 \mathrm{~cm}$, weight $=81.5 \pm 6.7 \mathrm{~kg}$, age $=18.44 \pm .70$ years; defenders $=8$, height $=184.0 \pm 3.8 \mathrm{~cm}$, weight $=84.2 \pm 6.5 \mathrm{~kg}$, age $=18.60$ years \pm .59 ; attackers $=12$, height $=181.2 \pm 5.4 \mathrm{~cm}$, weight $=79.6 \pm 6.7 \mathrm{~kg}$, age $=18.33 \pm .77$ years) in a competitive year 2014/2015. The indicators of selected speed abilities were observed by two tests: 1 . Run to $40 \mathrm{~m}$ with changes of direction and agility 2. Test - Illinois. Statistical analysis was conducted by using the software IBM ${ }^{\circledR}$ SPSS ${ }^{\circledR}$ Statistics V19. The average value of the test run to $40 \mathrm{~m}$ with changes of the direction of the whole file was $8.52 \pm .22 \mathrm{~s}$, among defenders was $8.34 \pm .10 \mathrm{~s}$, among forwards $8.64 \pm$ $.19 \mathrm{~s}$, which is a statistically significant difference between defenders and forwards $(d=1.97 ; p<0.05$; $r=0.70$ - large effect) in favour of the defenders. In the agility test - Illinois, the average value of the whole file was $16.58 \pm .33 \mathrm{~s}$. For the defenders, the average finish time indicated of the value $16.32 \pm$ $.23 \mathrm{~s}$ and for forwards $16.75 \pm .27 \mathrm{~s}$, which again is statistically significant difference in favour of the defenders $(d=1.71 ; p<0.05 ; r=0.65$ - large effect $)$.
\end{abstract}

\section{Klúčové slová}

obrancovia, útočníci, juniorskí hokejisti.

\section{Key words}

defenders, forwards, juniors ice hockey players.

\section{Úvod}

L'adový hokej je charakteristický vysokou intenzitou pohybovej činnosti, trvajúcou približne 50 sekúnd až 1 minútu s viacerými opakovaniami. Jednotliví hráči sa striedajú pravidelne, najčastejšie 
$\mathrm{v}$ troch alebo štyroch formáciách. Počas jednej tretiny pri troch formáciách na každého hráča pripadá približne 6 až 7 intenzívnych činností, medzi ktorými je oddych približne 250 sekúnd pri hre na 4 formácie a rešpektovaním času pri prerušení hry. Na základe výskumov sa zistilo, že počas zápasu obranca nakorčuluje asi $5 \mathrm{~km}$ a útočník asi $7 \mathrm{~km}$. V jednotlivých striedaniach hráč korčuluje v priemere 500 až 600 metrov (maximálne 900, minimálne $200 \mathrm{~m}$ ). Priemerná rýchlost' je približne 15 $\mathrm{km} / \mathrm{h}$ a maximálna $38 \mathrm{~km} / \mathrm{h}$. Pri predpoklade pravidelného striedania troch kompletných formácií na jedného hráča pripadá 15 až 20 minút hry (Kostka, Bukač \& Šafařík 1986; Starší, Jančoková \& Výboh 1999; Pavliš et al. 2002; Šimonek \& Zrubák, 2003; Laczo, 2011).

Rýchlostné schopnosti charakterizujeme ako pohybovú schopnost' vykonávat' krátkodobú pohybovú činnost' čo najkratšie. Medzi dominantné pohybové schopnosti hráča l'adového hokeja zarad'ujeme rýchlostné schopnosti, ktoré sú geneticky podmienené a tréningovým procesom ovplyvnitel'né len čiastočne, v porovnaní so silovými a vytrvalostnými schopnost’ami. Dôležité je ale začat's ich ovplyvňovaním v optimálnom, citlivom období, tj. vo veku 10-14 rokov (Kasa, 2000; Sedláček et al., 2003; Koštial \& Kampmiller, 2003). Rýchlostné schopnosti majú vysoký podiel dedičnosti a dajú sa ovplyvnit' len na 10 až $15 \%$ (Šimonek \& Zrubák, 2003; Výboh et al., 2005; Moravec et al., 2007; Tóth et al., 2010).

Obsahom kondičného tréningu mimo l'adu sú predovšetkým cvičenia zamerané na špecializovaný rozvoj pohybových schopností. S ohl’adom na l'adový hokej získava preferenciu rozvoj rýchlostných, rýchlostno-silových, silových, silovo-vytrvalostných a koordinačných schopností. Všeobecný charakter má tento typ tréningu iba v prechodnom a prípravnom období (Pavliš et al., 2003).

V l'adovom hokeji sa rýchlostné schopnosti môžu rozvíjat' viacerými spôsobmi, či už pomocou špeciálnych cvičení na l'ade, alebo mimo l'adu. Pri výbere cvičení a zložení tréningovej jednotky je nutné prihliadat' najmä na vek hráčov, pričom by sme mali rešpektovat' najmä senzitívne obdobia na rozvoj rýchlostných schopností. Vel'mi často využívanou metódou na rozvoj rýchlosti je metóda plyometrie (Výboh, et al., 2005).

V štúdii sme sa zamerali na vekovú kategóriu juniorov (16-20 rokov), ktorá čo sa týka fyzickej vyzretosti hráčov sa podobá kategórii seniorov. Z hl’adiska intenzity a nasadenia v hre sa vyrovnávajú juniorské kategórie so seniorskými, čo zvyšuje nároky na kondíciu hráčov. Z uvedených dôvodov je potrebné sa zamerat' na zložitost', objem a intenzitu tréningového zataženia v prípravnom období a v sút'ažnom období.

Štúdia prezentuje výsledky výskumu zameraného na porovnanie úrovne vybraných rýchlostných schopností juniorských hokejistov z hl'adiska hráčskych postov tímu HC'05 Banská Bystrica v sút’ažnom ročníku 2014/2015.

\section{Metodika}

\section{Charakteristika výskumného súboru}

Súbor tvorili hokejisti juniorského družstva HC'05 Banská Bystrica $(\mathrm{n}=20$, výška $=182,3 \pm 4,9 \mathrm{~cm}$, hmotnost' $=81,5 \pm 6,7 \mathrm{~kg}$, vek $=18,44 \pm 0,70$ roka; obrancovia $=8$, výška $=184,0 \pm 3,8 \mathrm{~cm}$, hmotnost' $=$ $84,2 \pm 6,5 \mathrm{~kg}$, vek $=18,60 \pm 0,59$ roka; útočníci $=12$, výška $=181,2 \pm 5,4 \mathrm{~cm}$, hmotnost' $=79,6 \pm 6,7 \mathrm{~kg}$, vek $=18,33 \pm 0,77$ roka). Z pohl'adu držania hokejky bolo v družstve 17 l'avákov a 3 praváci. Výskumný súbor tvorili hráči, ktorí sa venovali l'adovému hokeju v priemere 7,9 $\pm 1,0$ roka.

Družstvo pôsobilo v skúmanom období v slovenskej najvyššej sút'aži kategórie juniorov organizovanej Slovenským zväzom l'adového hokeja.

\section{Organizácia meraní}

Diagnostika bola realizovaná dňa 27.6.2014 v prípravnom období sút’ažného ročníka 2014/2015 $\mathrm{v}$ priestoroch zimného štadióna $\mathrm{v}$ Banskej Bystrici $\mathrm{v}$ dopoludňajších hodinách, kedy môžeme v súlade s Jančokovou (2000) hovorit' o prvom dennom vrchole výkonnosti. Diagnostika rýchlostných schopností bola realizovaná $\mathrm{v}$ telocvični na elastickom polyuretánovom povrchu, ktorý bol protišmykový. 


\section{Realizácia meraní}

Na diagnostiku úrovne rýchlostných schopností sme použili štandardizovaný test - Beh na $40 \mathrm{~m}$ so zmenami smeru. Testovaný hráč štartoval s polovysokého štartu k protilahlej méte na zvukové znamenie trénera, kde hráč musel obidvoma nohami prekročit' čiaru a súčasne sa jej dotknút'. Zmena smeru sa vykonávala vždy tvárou k trénerovi. Čas sme merali s presnost'ou na $0,1 \mathrm{~s}$. Hodnotili a zapisovali sme najlepší čas z dvoch pokusov. Druhým testom bol Test agility - Illinois. Hráč štartoval s polovysokého štartu, bežal vpred od štartovej čiary potom pomedzi stojany slalomom a bežal až po ciel'ovú čiaru. V prípade, že hráč zhodil ktorýkol'vek stojan, pokus bol neplatný. Čas sme merali s presnost'ou na $0,1 \mathrm{~s}$.

\section{Štatistická analýza}

V prezentovanej štúdii sme v rámci opisných charakteristík deskriptívnej štatistiky použili z mier polohy aritmetický priemer (x) a z mier variability smerodajnú (štandardnú) odchýlku (SD). Využili sme aj minimálne (min) a maximálne (max) hodnoty skúmaných rýchlostných indikátorov. Pri interpretácii výsledkov sme použili effect size. Použili sme Cohenovo d, ktoré je možné použit' pri hodnotení efektu medzi dvomi nezávislými premennými. Výpočet d je daný rozdielom aritmetických priemerov medzi dvoma skupinami M1 a M2, ktorý je vydelený smerodajnou odchýlkou. Čitatel' M1 -M2 je číslo nezáporné v prípade, že M1 - M2 <0, berieme do úvahy absolútnu hodnotu rozdielov alebo hodnotu M2 -M1. Bežne používané hodnotenie vel'kosti koeficientu d je nasledujúca (Cohen, 1988; Sheskin, 2007):

- $\mathrm{d} \geq 0,80 \rightarrow$ vel'ký efekt,

- $\mathrm{d}$ je $\mathrm{z}$ intervalu $<0,50-0,80) \rightarrow$ stredný efekt,

- $\mathrm{d}$ je $\mathrm{z}$ intervalu $<0,20-0,50) \rightarrow$ malý efekt.

Štatistická analýza bola realizovaná prostredníctvom softvéru IBM ${ }^{\circledR}$ SPSS ${ }^{\circledR}$ Statistics V19 (Statistical Package for the Social Sciences).

\section{Výsledky}

Komparáciu hráčskych postov z hl'adiska aktuálnej úrovne vybraných indikátorov rýchlostných schopností v prípravnom období sme analyzovali na základe výsledkov testov (1. Beh na $40 \mathrm{~m}$ so zmenami smeru a 2. Test agility - Illinois).

Tabulka 1: Úroveň rýchlostných schopností - beh na 40m so zmenami smeru (s) prípravné obdobie

\begin{tabular}{|c|c|c|c|}
\hline $\begin{array}{c}\text { Beh na 40m so } \\
\text { zmenami smeru }\end{array}$ & Súbor & Obrancovia & Útočníci \\
\hline $\mathbf{x}$ & $8,52 \pm 0,22$ & $8,34 \pm 0,10$ & $8,64 \pm 0,19$ \\
\hline $\min$ & 8,15 & 8,21 & 8,15 \\
\hline $\max$ & 8,90 & 8,47 & 8,9 \\
\hline \multicolumn{2}{|c|}{ Mann - Whitney U test; effect size } & $\mathrm{d}=1,97 ; \mathrm{p}<0,05 ; \mathrm{r}=0,70$ \\
\hline
\end{tabular}

Priemerná hodnota merania behu na $40 \mathrm{~m}$ so zmenami smeru výskumného súboru bola $8,52 \pm$ $0,22 \mathrm{~s}$, najlepší zaznamenaný čas bol $8,15 \mathrm{~s}$ a najhorší čas $8,90 \mathrm{~s}$. Priemerná hodnota merania behu na $40 \mathrm{~m}$ so zmenami smeru u obrancov bola $8,34 \pm 0,10 \mathrm{~s}$ a útočníkov $8,64 \pm 0,19 \mathrm{~s}$. Z pohl'adu času celého súboru dosiahli obrancovia lepší priemerný čas o $0,18 \mathrm{~s}$ a útočníci horší priemerný čas o 0,12 $\mathrm{s}$ v porovnaní s celým súborom. Rozdiel medzi obrancami a útočníkmi bol štatisticky významný $(\mathrm{d}=1,97 ; \mathrm{p}<0,05 ; \mathrm{r}=0,70$ - vel'ký efekt, tabul'ka 1$)$. 
Tabulka 2: Úroveň rýchlostných schopností - test agility - Illinois (s) prípravné obdobie

\begin{tabular}{|c|c|c|c|}
\hline Test agility - Illinois & Súbor & Obrancovia & Útočníci \\
\hline $\mathbf{x}$ & $16,58 \pm 0,33$ & $16,32 \pm 0,23$ & $16,75 \pm 0,27$ \\
\hline $\min$ & 16,05 & 16,05 & 16,4 \\
\hline $\max$ & 17,25 & 16,7 & 17,25 \\
\hline \multicolumn{2}{|c|}{ Mann - Whitney U test; effect size } & \multicolumn{2}{|c|}{$d=1,71, \mathrm{p}<0,05 ; \mathrm{r}=0,65$} \\
\hline
\end{tabular}

Priemerná hodnota merania testu agility - Illinois celého súboru bola $16,58 \pm 0,33 \mathrm{~s}$, najlepší zaznamenaný čas bol 16,05 s a najhorší 17,25 s. Priemerná hodnota obrancov bola 16,32 $\pm 0,23$ $\mathrm{s}$ a útočníkov $16,75 \pm 0,27 \mathrm{~s}$. Z pohl'adu priemerného času celého súboru dosiahli obrancovia lepší čas o $0,26 \mathrm{~s}$ a útočníci horší čas o $0,17 \mathrm{~s}$ v porovnaní s celým súborom. Rozdiel medzi obrancami a útočníkmi bol štatisticky významný $(\mathrm{d}=1,71 ; \mathrm{p}<0,05 ; \mathrm{r}=0,65$ - vel'ký efekt, tabul'ka 2$)$.

\section{Diskuse}

Diagnostika pohybovej výkonnosti hokejistov je prepojením teórie a praxe. Pre úspešnú realizáciu vyhodnotenia diagnostického procesu je nutné dodržiavat' určité zásady merania. Dbáme na výber vhodnej testovacej batérie, štandardné vonkajšie podmienky, motiváciu hráčov a najdôležitejšia zásada je, akým spôsobom budeme získané výsledky vyhodnocovat'. Hráčov sme oboznámili s tým, o aké testy pôjde, vysvetlili sme postup testovania, aby výsledky mohli byt' platné. Pri hodnotení disciplín beh na $40 \mathrm{~m}$ so zmenami smeru a agility - Illinois by bolo vhodnejšie merat' časy pomocou fotobuniek. (Tóth et al., 2010b).

Súhlasíme s Pivovarničkom et al. (2014), že diagnostika pohybových schopností môže byt' rozhodujúcim faktorom úrovne jednotlivca, najmä obmedzení pohybových schopností, pre trénerov a realizačné tímy športových tímov. Na druhú stranu, ani vynikajúca úroveň pohybových schopností sa automaticky nemusí premietnut' do individuálneho herného výkonu a herného výkonu družstva. Nedostatočná úroveň pohybových schopností limituje herný výkon, najmä na vrcholovej úrovni, kde detaily rozhodujú zápasy.

Problematikou vplyvu výkonnosti na suchu na výkonnost' na l'ade sa zaoberali v štúdii (Janot, Beltz \& Dalleck, 2015). Dospeli k záveru, že významnými faktormi, ktoré umožňujú predvídat' výkonnost' korčul'ovania z pohl'adu rýchlosti sú testy: beh na 40 yardov a vertikálny výskok. Medzi dominantné pohybové schopnosti hráča l'adového hokeja zarad’ujeme rýchlostné schopnosti, ktoré sú geneticky podmienené a tréningovým procesom ovplyvnitel'né len čiastočne, v porovnaní so silovými a vytrvalostnými schopnost’ami. Moravec et al. (2007) a Tóth et al. (2010a) zhodne uvádzajú, že rýchlostné schopnosti sú najviac geneticky podmienené a dajú sa ovplyvnit' len na 10 až $15 \%$.

Z hl'adiska porovnania nami skúmaných indikátorov rýchlostných schopností jednotlivých hráčskych postov dosiahli obrancovia $\mathrm{v}$ obidvoch testoch signifikantne lepšie výsledky. Podobne ako Pivovarniček et al. (2014) sme dospeli k záveru, že problematika úrovne rýchlostných schopností z hl'adiska hráčskych postov môže byt' pomocným indikátorom pri sledovaní a interpretácii úspešnosti v rôznych herných situáciách, napr. herná situácia útočník - obranca alebo opačne. Jednými z limitujúcich faktorov v l'adovom hokeji je dostatočná úroveň rýchlostno-silových schopností, ktoré sa prejavujú v akcelerácii hráča, v strel'be, v osobných súbojoch aj v iných činnostiach (Kabát \& Vanderka, 2013). Súhlasíme s Duthie et al. (2006), že akcelerácia je v tímových športoch dôležitá. Rovnako ako vo futbale vysoká úroveň rýchlostných schopností špeciálne akceleračného charakteru vytvára väčší predpoklad získania puku skôr ako protihráč, čím má pod kontrolou hernú situáciu a d’alší vývoj hry (Pivovarniček et al., 2014).

V budúcnosti by bolo potrebné realizovat’ výskum so zameraním na testovanie rýchlostných schopností aj na l’ade. Získané údaje by bolo možné porovnat's výsledkami testov mimo l’adu. 
Výskumom vzt'ahov rýchlosti meranej na l'ade a mimo l'adu sa zaoberali Farlinger \& Fowles (2008) a dospeli $\mathrm{k}$ nasledovným záverom. Jedine test $30 \mathrm{~m}$ šprint $(\mathrm{r}=0,56 ; \mathrm{p}=0,010)$ a Edgren side shuffle $(\mathrm{r}=-0,46, \mathrm{p}<0,040)$, boli testy na suchu, ktoré významne korelovali so zlepšením rýchlosti korčul'ovania na l'ade. Krause et al. (2012) uvádzajú, že výsledky testu beh na 40 yardov umožňujú predvídat' výkonnost' v korčul'ovaní vpred.

V l’adovom hokeji sú rýchlostné prejavy viazané na špecifickú motoriku, určovanú korčulovaním a činnost'ou na l'ade. V hokejovej príprave sa uplatňujú a plánujú tréningy na l'ade a mimo l'ad. Korelačná analýza v štúdii Bukač \& Dovalil (1990) ukázala, že rýchlost' behu a korčul'ovania na krátkych úsekoch spolu nesúvisí. Taktiež následný experiment viedol k záveru, že zlepšenie v ukazovatel'och rýchlosti behu sa neodrazilo na rýchlosti korčul'ovania. Výsledky tak potvrdzujú vysokú špecifickost' rýchlostných schopností v l'adovom hokeji.

Uvedené výsledky a tvrdenia sú vhodným námetom pre realizáciu d’alších výskumov, čo sa týka úrovne rýchlostných schopností hokejistov mimo l'adu aj na l'ade. Ešte dôležitejšou skutočnost'ou sa ukazuje aj zist'ovanie vzt'ahov medzi výsledkami dosiahnutými na l'ade aj mimo l'adu, pretože pre individuálny herný výkon hokejistu má význam rýchlost' na l'ade či už s vedením puku, alebo bez neho.

\section{Závery}

Úroveň rýchlostných schopností sme zistovali testom Beh na $40 \mathrm{~m}$ so zmenami smeru a Test agility - Illinois. Priemerná hodnota merania behu na $40 \mathrm{~m}$ so zmenami smeru výskumného súboru bola 8,52 $\pm 0,22 \mathrm{~s}$, najlepší zaznamenaný čas bol 8,15 s a najhorší čas 8,90 s. Priemerná hodnota merania behu na $40 \mathrm{~m}$ so zmenami smeru u obrancov bola $8,34 \pm 0,10 \mathrm{~s}$ a útočníkov $8,64 \pm 0,19$ s. Z pohl'adu času celého súboru dosiahli obrancovia lepší priemerný čas o $0,18 \mathrm{~s}$ a útočníci horší priemerný čas o $0,12 \mathrm{~s}$ v porovnaní s celým súborom. Rozdiel medzi obrancami a útočníkmi bol štatisticky významný $(\mathrm{d}=1,97 ; \mathrm{p}<0,05 ; \mathrm{r}=0,70-$ vel'ký efekt). Priemerná hodnota merania testu agility - Illinois celého súboru bola 16,58 $\pm 0,33 \mathrm{~s}$, najlepší zaznamenaný čas bol 16,05 s a najhorší $17,25 \mathrm{~s}$. Priemerná hodnota obrancov bola $16,32 \pm 0,23 \mathrm{~s}$ a útočníkov $16,75 \pm 0,27 \mathrm{~s}$. Z pohl'adu priemerného času celého súboru dosiahli obrancovia lepší čas o $0,26 \mathrm{~s}$ a útočníci horší čas o 0,17 $\mathrm{s} v$ porovnaní s celým súborom. Rozdiel medzi obrancami a útočníkmi bol štatisticky významný $(\mathrm{d}=1,71 ; \mathrm{p}<0,05 ; \mathrm{r}=0,65-$ vel'ký efekt $)$.

Výskumom sme dospeli k záveru, že úroveň rýchlostných schopností v prípade hráčov súboru je z hl'adiska hráčskych postov rozdielna. Vyššiu úroveň rýchlostných schopností v obidvoch použitých testoch dosiahli obrancovia.

\section{Literatúra}

Cohen, J. (1988). Statistical power analysis for the behavioral sciences (2nd edn). New York: Academic Press.

Bukač, L. \& Dovalil, J. (1990). Lední hokej. Trénink herní dokonalosti. Praha, CZ: Olympia.

Duthie, G. M., Pyne, D. B., Ross, A. A., Livingstone, S. G., \& Hooper, S. L. (2006). The reliability of ten-meter sprint time using different starting techniques. Journal of Strength and Conditioning research, 20, 246-251.

Farlinger, CM. \& Fowles, JR. (2008). The effect of sequence of skating-specific training on skating performance. Int J Sports Physiol Perform. 2008 Jun;3(2):185-98.

Janot, J. M., Beltz, N. M. \& Dalleck, L. D. (2015). Multiple Off-Ice Performance Variables Predict On-Ice Skating Performance in Male and Female Division III Ice Hockey Players. J Sports Sci Med. 2015 Sep; 14(3): 522-529. PMCID: PMC4541115.

Jančoková, L. (2000). Biorytmy v športe (S úvodom do chronobiológie) [Biorhythms in sport (With an introduction to chronobiology)]. Banská Bystrica, SK: FHV UMB.

Kabát, M. \& Vanderka, M. (2013). Vplyv všeobecného a kombinovaného silového tréningu na rýchlostno-silové schopnosti mladých hokejistov. In Kondičný tréning v roku 2013. Banská Bystrica, SK: FHV UMB.

Kostka, V., Bukač, L. \& Šafařík, V. (1986). Lední hokej-teórie a didaktika. Praha. SNP.

Koštial, J. \& Kampmiller, T. (2003). Rýchlostné schopnosti. In Šimonek, J. - Zrubák, A. 2003. Základy kondičnej prípravy v športe. Bratislava, SK: FTVŠ UK. 
Krause, DA., Smith, AM., Holmes, LC., Klebe, CR., Lee, JB., Lundquist, KM., Eischen, JJ., \& Hollman JH. (2012). Relationship of off-ice and on-ice performance measures in high school male hockey players. J Strength Cond Res. 2012 May;26(5):142330. doi: 10.1519/JSC.0b013e318251072d.

Laczo, E. (2011). Riadenie tréningového a zápasového zat'aženia. [online] Publikované 2011 [Citované 21.12.2015] Dostupné z http://www.hockeyslovakia.sk/userfiles/file/Informacie\%20zo\%20sveta/Eugen-Laczo-SVK-senior.pdf

Moravec, R., Kampmiller, T., Vanderka, M. \& Laczo, E. (2007). Teória a didaktika výkonnostného a vrcholového športu. Bratislava, SK: FTVŠ UK.

Pavliš, Z., Dovalil, J., Šindel, J., Pešout, M., Perič, T., Mazanec, M., Hynek, P. \& Novák, Z. (2002). Přiručka pro trenéry ledního hokeje, III. Část. Praha : ČSLH.

Pavliš, Z., Perič, T., Heller, J., Jansa, P. \& Čáslavová, E. (2003). Školení trenérů ledního hokeje. Vybrané obecné obory. Praha, CZ: ČSLH.

Pivovarniček, P., Pupiš, M., Švantner, R. \& Kitka, B. (2014). A Level of Sprint Ability of Elite Young Football Players at Different Positions. International Journal of Sports Science 2014, 4(6A): 65-70. DOI: 10.5923/s.sports.201401.09

Sheskin, D. J. (2007). Handbook of parametric and nonparametric statistical procedures (4th ed.). Boca Raton, FL: Chapman \& Hall/CRC.

Starší, J., Jančoková, L. \& Výboh, A. (1999). Teória a didaktika ladového hokeja. Vysokoškolské učebné texty. Banská Bystrica : UMB FHV.

Šimonek, J. \& Zrubák, A. (2003). Základy kondičnej prípravy v športe. Bratislava, SK: FTVŠ UK.

Tóth, I., Bielik, V., Binovský, A., Duchoslav, L., Duvač, I., Filc, J., Grauzel, J., Gregor, T., Hamar, D., Chandoga, I., Jančovič, D., Laczo, E., Peráčková, J., Psalman, V., Sakáčová, Z., Šatan, E., Vavrovič, D. \& Žák, F. (2010b). Ladový hokej. Vysokoškolská učebnica aplikovaných predmetov pre trénerov špecializácie v l'adovom hokeji. 1. vyd. Bratislava, SK: TO - MI Ice Hockey Agency.

Tóth, I., Andrejkovič, I., Bača, J., Filc, J., Jurčenko, R., Jurica, M., Kožanová, L., Munka, J., Pokovič, L., Štastný, V. \& Výboh, A. (2010a). Tréner ladového hokeja. Vysokoškolská učebnica pre trénerov špecializácie v ladovom hokeji. 1. vyd. . Bratislava, SK: TO - MI Ice Hockey Agency.

Výboh, A., Starší, J., Frühwald, I., Kútik, S. \& Noga, D. (2005). Teória a didaktika ladového hokeja III.

\section{Corresponding author}

Mgr. Rastislav Pal'ov

Filozofická fakulta, Univerzita Mateja Bela, Tajovského 40, 97401 Banská Bystrica, Slovakia rastislav.palov@umb.sk 